\title{
Social impacts of using a solar panel for rural coastal communities: A case study from Karimun Regency, Kepulauan Riau
}

\author{
Wayu Eko Yudiatmaja ${ }^{1,}$, Sri Wahyuni ${ }^{2}$, Fitri Kurnianingsih ${ }^{1}$, Mahadiansar Mahadiansar ${ }^{3}$, \\ Rahayu Sulistiowati ${ }^{4}$, Mohammad Kus Yunanto ${ }^{5}$, Fifi Nofiyanti ${ }^{6}$, and Tri Samnuzulsari ${ }^{2}$ \\ ${ }^{1}$ Department of Public Administration, Universitas Maritim Raja Ali Haji, Tanjungpinang, Indonesia \\ ${ }^{2}$ Department of Sociology, Universitas Maritim Raja Ali Haji, Tanjungpinang, Indonesia \\ ${ }^{3}$ Department of Public Administration, Universitas Brawijaya, Malang, Indonesia \\ ${ }^{4}$ Department of Public Administration, Universitas Lampung, Bandar Lampung, Indonesia \\ ${ }^{5}$ Sekolah Tinggi Ilmu Administrasi “AAN”, Yogyakarta, Indonesia \\ ${ }^{6}$ STP Trisakti, IKPN Bintaro, Tanah Kusir, 12330, Jakarta, Indonesia Indonesia
}

\begin{abstract}
The Indonesian government has implemented a solar panel policy to overcome a limitation of electrical availability in remote islands. Unfortunately, the prior studies have given a little concern to examine the social effect of the policy. Therefore, this paper addresses the research gap by testing the difference in social impacts of solar cell usage. Before and after analysis was used in this study. This research was conducted using a survey approach on two rural coastal communities in Karimun Regency, Kepulauan Riau, Indonesia. The research was arranged from May to October 2019. The respondent was chosen using simple random sampling. 262 respondents from these regions were voluntarily involved in the survey. Data were analysed using descriptive statistics and a paired sample $t$-test by applying SPSS. The findings reveal that there are significant differences in communities' social capital in terms of social relationships, trust, participation in the community, and brotherhood, before and after the policy is applied. Although solar panels provide many conveniences to society, social capital decreases to a lower level than before. The contributions of the research to the theory and practice are discussed.
\end{abstract}

\section{Introduction}

Indonesian government strives to realize energy equality for rural and villages in remote Islands all over the region. In addition to providing affordable energy, the government must also make a transition to a renewable and low-carbon system that is targeted, consistent, inclusive, and has clear targets and indicators. One way is to prioritize the use of decentralized renewable energy by leveraging local renewable resources and technologies. This strategy is important because it can reach many underdeveloped areas, the use of

*Corresponding author: wayuguci@umrah.ac.id 
renewable energy that is in accordance with the local potential such as water, sunlight, wind, and biomass, as well as ocean waves is an economical option for the long term [1].

Several programmes are introduced to address unequal energy in the Indonesian region. One of the programmes is solar panel assistance for a community in the villages on the remote islands. It is an aid to solve the problem of electricity needs in remote villages, as well as to reduce the dependence on fossil energy. This programme is entirely funded by Deutsche Gesellschaft für Internationale Zusammenarbeit (GIZ) [2]. The implementation of the programme is conducted through a collaboration between the Ministry of Marine and Fisheries and the Ministry of Energy and Mineral Resources. The programme is conducted by delivering solar panel facilities to households in remote islands area in several provinces in Indonesia. Solar power plants with a total capacity of $135.01 \mathrm{MWp}$ have been constructed in several regions throughout Indonesia since the program's inception. The government has a positive strategy to expand the program until it reaches $250 \mathrm{MWp}$ by 2025 [3].

One of the regions obtaining the relief is Karimun Regency in Kepulauan Riau. Tanjung Batu Kecil and Tanjung Hutan are two villages admitting the assistance in Karimun. Tanjung Batu Kecil village received solar power plant lighting assistance in 2015. Based on the village administration data, the village government received assistance in the form of a $75 \mathrm{KWp}$ capacity of solar panel with an allocation of 300 watts per day. In March 2016 the solar power plant can be enjoyed by the community in the village. There are around 534 households in Tanjung Hutan and 595 households in Tanjung Batu Kecil as the list of recipients of the power plant assistance. Even though they receive a small power, the people are extremely grateful for the programme because it helps to address their electrical problem.

Several works have addressed the impact of the new technology adoption policy in Indonesia. For instance, Putra et al. studied the effect of adopting biogas technology on Indonesian farmers. Their findings revealed that smallholder farmers in Indonesia use less firewood after adopting biogas technology. Nevertheless, the effect utilising of sludge as an organic fertilizer and the application of gas as a household cooking fuel could not be assessed [4]. Yudithia et al. evaluated the economic effect of using solar cells in rural coastal communities at Kepulauan Riau. By using a before and after evaluation model, they found that the adoption of solar cells affected income, expenditure, and the business chance of fishermen households [5]. Setyawati analysed the perceptions of the user in adopting solar panels in urban Indonesia. Using an online survey, she pointed out that the users revealed that several problems in using a solar panel, including high cost economic, longterm return investment, and limited support from the state electricity company (PLN) and the government [6].

Although these studies have investigated how new technology adopted by the society can affect their life, a limited number of studies gives attention to the social impact of new technology adoption. In addition, prior studies also merely focused on the case of rural agrarian households in order to tend to ignore rural coastal communities [7]. This study fills the research gap in current literature by evaluating the social impacts of the solar panel programme. The objective of the current research is to investigate the social impacts of the policy by analysing the case of fishermen's households using before and after evaluation.

\section{Methods}

A survey approach was applied in this study to achieve the research's objectives. It was conducted on the households using solar panel in two villages, Tanjung Batu Kecil and Tanjung Hutan, in the Karimun Regency, Kepulauan Riau. These villages were chosen because they had received the programme in 2015 and it is currently persisted by the 
communities. This study was conducted from May to October 2019. The population of this research was all recipients of solar panels, 595 households from Tanjung Batu Kecil and 534 households from Tanjung Hutan. Using Krejcie \& Morgan's [8] formula, the sample in this research was 287 households. In fact, only 262 households were involved in the survey, thereby the response rate was 91.29 percent. The process of data collection was supported by ten research assistances. The researchers successfully interviewed 262 respondents using a questionnaire. The questionnaire was proposed by referring to the theory and concept used. Before distributing the questionnaire, the researchers discussed the questionnaire with the member of the research team and early tested on a limited sample. The researchers distributed the questionnaire after ensuring it was appropriate to be used.

The questionnaire consisted of two sections, including general information about the respondent and surveyed questions. The community's social capital was adapted from previous studies, such as Onyx and Bullen [9], and Engbers, Thompson, and Slaper [10]. It reflected four measurement variables, incorporating social relationships, trust, participation in the community, and brotherhood. Every variable had 3 items, assessed by using a five Likert's scale, ranging from never to frequently, so that all variables had 12 items. Social relationships referred to a reciprocal relationship between individuals with one another, affecting each other, and are based on awareness to help each other. Trust is related to an attitude showing mutual trust between individuals in society. Community participation was an individual involved in all stages or processes of social activities in a community group. Brotherhood could be defined as a relationship or inner bond between one person and another which cannot be separated.

From all variables and categories of policy, we offered four hypotheses further examined: (1) There was a significant difference in social relationships before and after policy implemented, (2) There was a significant difference of trust before and after policy implemented, (3) There was a significant difference of participation in the community before and after policy implemented, and (4) There was a significant difference of brotherhood before and after policy implemented.

Data were processed by applying a statistical package for social sciences (SPSS) and displayed into descriptive statistics and hypotheses testing. A paired sample $t$-test was performed to identify the difference in social capital between before and after policy execution [11]. A significance level of paired $t$-test was used as a basis for attracting the results. The basis of decision-making for hypotheses testing was the significance level ( $p$ value). There was a difference if the outputs were significantly lower than 0.05 . However, it was to be no difference if the significance is above 0.05 .

\section{Results and Discussion}

\subsection{Results}

The demographic profile of the respondents relied on the respondent's sex, age, educational level, and monthly expenditure, as exhibited in Table 1. The demographic conditions showed that from 262 respondents responding to our surveys, 60.7 percent were female and 39.3 percent were male. It revealed that majority of the respondents was female because most of females or fishermen's wife stayed at home when the research was performed. The average respondent's age was more than 40 years, and roughly 95 percent were married. The educational background of the respondents was slightly low, with almost 83 percent were only junior high school, indicating the low educational opportunity for the people in Indonesian remote islands. The monthly respondent's expenditure was diverse in which more than 56 percent of the respondents spent their money around IDR 1,000,000- 
$1,800,000$ a month. The respondents of this research were slightly similar to Yudhitia's et al. study [5].

Table 1. Respondent's characteristics

\begin{tabular}{|c|l|c|c|}
\hline Category & \multicolumn{1}{|c|}{ Item } & Amount & Percentage \\
\hline \multirow{2}{*}{ Gender } & Male & 103 & 39.3 \\
& Female & 159 & 60.7 \\
\hline \multirow{2}{*}{ Age } & $21-40$ & 101 & 38.6 \\
& $>40$ & 161 & 61.5 \\
\hline \multirow{3}{*}{ Educational Level } & Junior High School & 216 & 82.4 \\
& Senior High School & 41 & 15.7 \\
& Diploma and Bachelor & 5 & 1.9 \\
\hline \multirow{5}{*}{ Monthly Expenditure (IDR) } & 6600,000 & 2.3 \\
& $600,000-1,000,000$ & 78 & 29.8 \\
& $1,000,000-1,800,000$ & 148 & 56.5 \\
& $1,800,000-3,000,000$ & 29 & 11.1 \\
& $>3,000,000$ & 1 & 0.4 \\
\hline
\end{tabular}

Validity and reliability of the data before and after the programme were checked by assessing loading factors and Cronbach alpha. As the rule of thumb, the data were valid if the loading factors were above 0.5 and reliable if the Cronbach alpha was greater than 0.6 [12]. A Spearman correlation was used to analyse validity using SPSS. As seen in Table 2, results revealed all loading factors of each variable more than 0.5 , meaning that the data were valid. The findings also showed that Cronbach alpha exceeded 0.6, implying that the data were reliable and can be further analysed.

Table 2. Validity and Reliability Test

\begin{tabular}{|c|c|c|c|c|}
\hline \multirow{2}{*}{ Item } & \multicolumn{2}{|c|}{$\begin{array}{c}\text { Before Programme } \\
\text { Implemented }\end{array}$} & \multicolumn{2}{|c|}{$\begin{array}{l}\text { After Programme } \\
\text { Implemented }\end{array}$} \\
\hline & Loading & $\begin{array}{l}\text { Cronbach } \\
\text { Alpha }\end{array}$ & Loading & $\begin{array}{l}\text { Cronbach } \\
\text { Alpha }\end{array}$ \\
\hline $\begin{array}{l}\text { Social Relationships } \\
\text { 1. I always greet other people I } \\
\text { know } \\
\text { 2. I always arrive if the people } \\
\text { invite me } \\
\text { 3. I am willing to cooperate } \\
\text { with others when asked }\end{array}$ & $\begin{array}{l}0.732 \\
0.771 \\
0.569\end{array}$ & 0.648 & $\begin{array}{l}0.818 \\
0.804 \\
0.639\end{array}$ & 0.612 \\
\hline $\begin{array}{l}\text { Trust } \\
\text { 1. I always believe in my } \\
\text { neighbour to help me if I ask } \\
\text { 2. I believe that my neighbour } \\
\text { always cares about me and } \\
\text { my family } \\
\text { 3. I believe that my neighbour } \\
\text { helps me selflessly }\end{array}$ & $\begin{array}{l}0.759 \\
0.643\end{array}$ & 0.668 & $\begin{array}{l}0.862 \\
0.738\end{array}$ & 0.627 \\
\hline
\end{tabular}




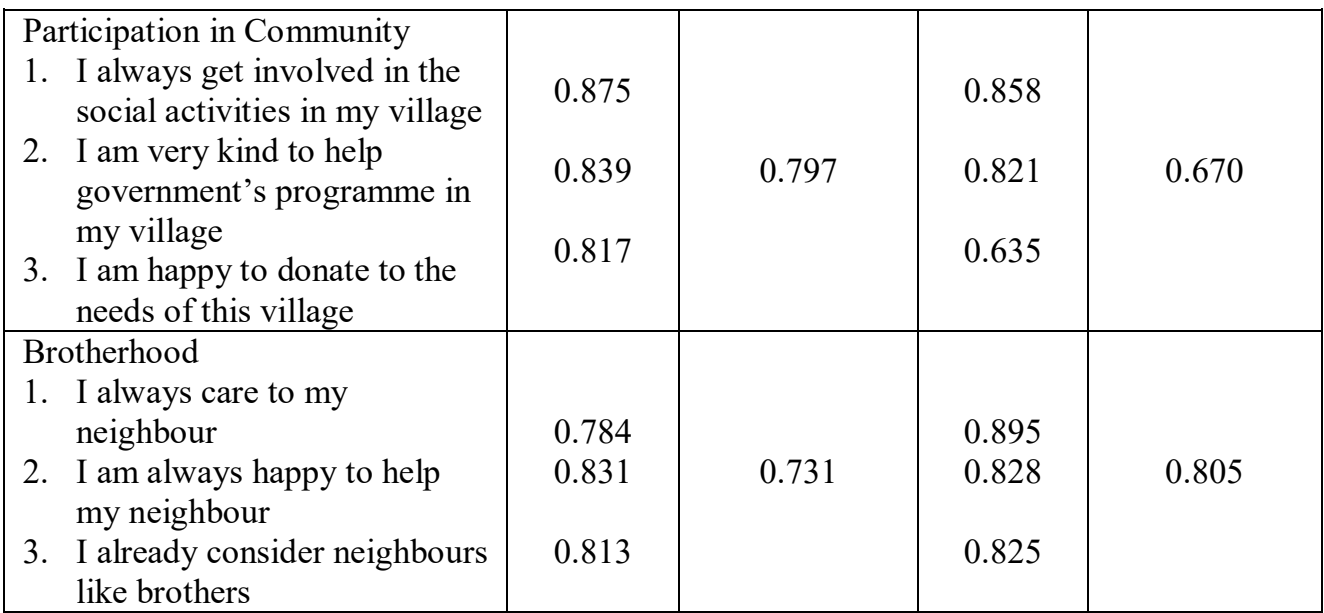

This study seeks the difference in the social capital of rural coastal communities before and after solar panel assistance, in terms of social relationship, trust, participation in the community, and brotherhood. Using paired sample $t$-test, the research achieves the study's purpose. Before testing the hypotheses, we ensure the data to fill normality and homogeneity tests. The tests show the data free of normality and homogeneity issues and can be further analysed.

As illustrated in Table 3, 4, and 5, a series of $t$-test calculation depict a significant different in social relationship before (Mean $=12.244, S D=1.544$ ) compare to after the programme executed (Mean $=11.542, S D=2.028$ ), $t=5.481 ; p=.000$. Therefore, Hypothesis 1 is supported. In term of community's trust, there is significant different between before (Mean $=12.057, S D=1.724)$ compare to after the programme implemented (Mean $=10.912, S D=2.557), t=7.917 ; p=.000$. Thus, Hypothesis 2 is accepted. In term of participation in community, there is significant different between before (Mean = $12.061, S D=2.046$ ) compare to after the programme implemented (Mean $=10.863, S D=$ 2.744), $t=6.616 ; p=.000$. Thus, Hypothesis 3 is supported. In term of brotherhood, there is significant different between before (Mean $=12.187, S D=1.984)$ compare to after the programme implemented (Mean $=10.107, S D=3.068), t=9.656 ; p=.000$. Thus, Hypothesis 4 is supported.

Table 3. Paired Sample Statistics

\begin{tabular}{|c|c|c|c|c|c|}
\hline \multicolumn{2}{|c|}{ Variable } & Mean & N & $\begin{array}{c}\text { Std. } \\
\text { Deviation }\end{array}$ & $\begin{array}{c}\text { Std. Error } \\
\text { Mean }\end{array}$ \\
\hline \multirow{2}{*}{ Social Relationship } & Before & 12.244 & 262 & 1.544 & .095 \\
\cline { 2 - 6 } & After & 11.542 & 262 & 2.028 & .125 \\
\hline \multirow{2}{*}{ Trust } & Before & 12.057 & 262 & 1.724 & .107 \\
\cline { 2 - 6 } & After & 10.912 & 262 & 2.557 & .158 \\
\hline \multirow{2}{*}{$\begin{array}{c}\text { Participation in } \\
\text { Community }\end{array}$} & Before & 12.061 & 262 & 2.046 & .126 \\
\cline { 2 - 6 } Brotherhood & After & 10.863 & 262 & 2.744 & .170 \\
\hline \multirow{2}{*}{ Before } & 12.187 & 262 & 1.984 & .123 \\
\cline { 2 - 6 } & After & 10.107 & 262 & 3.068 & .190 \\
\hline
\end{tabular}


Table 4. Paired Sample Correlations

\begin{tabular}{|c|c|c|c|}
\hline Variable & N & Correlation & Sig. \\
\hline Social Relationship & 262 & .350 & $.000^{*}$ \\
\hline Trust & 262 & .457 & $.000^{*}$ \\
\hline $\begin{array}{c}\text { Participation in } \\
\text { Community }\end{array}$ & 262 & .278 & $.000^{*}$ \\
\hline Brotherhood & 262 & .098 & .113 \\
\hline$p<0.05$ (significance level)
\end{tabular}

Table 5. Paired Sample T-Test

\begin{tabular}{|c|c|c|c|c|c|c|}
\hline Variable & Mean & $\begin{array}{c}\text { Std. } \\
\text { Deviation }\end{array}$ & $\begin{array}{c}\text { Std. } \\
\text { Error } \\
\text { Mean }\end{array}$ & $\boldsymbol{t}$ & $\boldsymbol{d} \boldsymbol{f}$ & $\begin{array}{c}\text { Sig. } \\
\text { (2 tailed) }\end{array}$ \\
\hline $\begin{array}{c}\text { Social } \\
\text { Relationship }\end{array}$ & .702 & 2.074 & .128 & 5.481 & 261 & $.000^{*}$ \\
\hline $\begin{array}{c}\text { Trust } \\
\begin{array}{c}\text { Participation } \\
\text { in }\end{array}\end{array}$ & 1.145 & 2.341 & .145 & 7.917 & 261 & $.000^{*}$ \\
\hline Community & 1.198 & 2.932 & .181 & 6.616 & 261 & $.000^{*}$ \\
\hline Brotherhood & 2.080 & 3.487 & .215 & 9.656 & 261 & $.000^{*}$ \\
\hline
\end{tabular}

$p<0.05$ (significance level)

\subsection{Discussion}

The results suggest that all hypothetical prepositions are accepted in this present investigation. Four main findings are achieved by this study. First, the mean score before and after the application of this program is .702, and there is a significant difference in social relationships before and after the implementation of this programme. It claims that the installation of solar panels reduces several aspects of social relationships in the rural community. Three items of social relationship, including "I always greet other people I know", "I always arrive if the people invite me", and "I am willing to cooperate with others when asked" diminish because of the programme. The findings are similar to preceding studies indicating the reduction of social relationships after implementing such social policy in rural Indonesia [13,14].

Second, the degree of trust has decreased following programme implementation. Before and after implementation, there is a significant difference in terms of the trust. All indicators of trust, such as "I always believe in my neighbour to help me if I ask", "I believe that my neighbour always cares about me and my family", and "I believe that my neighbour helps me selflessly" alleviate after the programme. The shrinking of community trust is affected by the individual's response to the social environment growing to be an exhaustively individualistic community. When people realise that other people are selfish, they become distrustful of their community. In sum, the people become distrust while accepting solar panels because of their direct response to the group. The results are consistent with past studies drawing the consequence of modernity on the erosion of trust $[15,16]$.

Third, when comparing before and after the program, the average level of community participation decreases. The statistical result also reveals a significant difference in community participation before and after the intervention. It should be noted that the solar panel programme relieves all items of participation in the community, incorporating "I always get involved in the social activities in my village", "I am very kind to help 
government's programme in my village", and "I am happy to donate to the needs of this village". Because of solar panels, the villagers receive better electricity than before and make them regularly stay at home for watching TV, browsing the internet, and gaming on cell phones. These activities reduce their intention to socialise and get involved in the community. In other words, people change to be individualistic after receiving solar panels because they enjoy much virtual entertainment and leisure in the home. These findings support several works explaining the effect of technological advancement on reducing social capital $[17,18]$.

The final point is that brotherhood has a greater deficit than other social capital dimensions, which is statistically significant. All aspects of brotherhood, such as "I always care to my neighbour", "I am always happy to help my neighbour", "I already consider neighbours like brothers" are negatively related to the solar panel programme. The assistance has destroyed social and cultural binding in the community. It occurs because the social relationship established by socio-cultural heritage transforms into an economic relationship. For example, because of solar panels the people can watch television privately in their homes and make an ice cube for sale. If their neighbours intend to join for watching television and obtain an ice cube, they have to pay an amount of money. Our findings confirm the earlier studies by a variety of scholars underlining the negative association between modernism and social capital $[19,20]$.

The findings of this study have an implication both theoretically and practically. In terms of theory, this research corroborates the discussion of social capital in policy implementation. This study completes the debate on social capital by highlighting the reduction of social capital after implementing social policy. The results can be a fruitful recommendation to the policymakers in designing social policy by anticipating the impact on the community's social capital. The government should completely prepare social policies before it is implemented, including the negative impact of the programme. Social workers can be involved by the government in implementing the programme to reduce the undesirable effect of the programme on the social circumstances of the community.

\section{Conclusion}

This study summarizes that all dimensions of social capital decrease because of the solar panel programme. The results also suggest that there are significant differences in the community's social capital before and after the programme was implemented. The distinctions occur in terms of social relationships, participation in community, trust, and brotherhood. In other words, the programme has decreased rural coastal attachment. The results corroborate the previous studies in different contexts finding that government assistance tends to negatively affect community binding. Therefore, our study has practical implications on the practice of social policy in Indonesia to pay attention to the decrease of the community's social capital after implementing the programme.

\section{References}

1. S. Thomas, M. Richter, W. Lestari, S. Prabawaningtyas, Y. Anggoro, and I. Kuntoadji, Energy Res. Soc. Sci. 45, 184 (2018).

2. A. B. Setyowati, Energy Res. Soc. Sci. 71, 101817 (2021).

3. The Ministry of Energy and Mineral Resources Republic of Indonesia, Kebijakan, Regulasi Dan Inisiatif Pengembangan Energi Surya Di Indonesia (The Policy, Regulation, and Initiation of the Development of Solar Energy in Indonesia) (Jakarta, 
2019).

4. R. A. R. S. Putra, Z. Liu, and M. Lund, Renew. Sustain. Energy Rev. 74, 1371 (2017).

5. Y. Yudithia, E. Edison, D. Kristanti, T. Samnuzulsari, S. Suyito, and W. E. Yudiatmaja, E3S Web Conf. 202, 1 (2020).

6. D. Setyawati, Energy Policy 144, 111569 (2020).

7. K. Takahashi, R. Muraoka, and K. Otsuka, Agric. Econ. 51, 31 (2020).

8. R. V Krejcie and D. W. Morgan, Educ. Psychol. Meas. 30, 607 (1970).

9. J. Onyx and P. Bullen, J. Appl. Behav. Sci. 36, 23 (2000).

10. T. A. Engbers, M. F. Thompson, and T. F. Slaper, Soc. Indic. Res. 132, 537 (2017).

11. J. L. Arbuckle, IBM SPSS Amos 22 User's Guide (IBM Corp., Chicago, IL, 2013).

12. J. F. Hair, W. C. Black, B. J. Babin, and R. E. Anderson, Multivariate Data Analysis, 7th Ed. (Prentice Hall, New Jersey, 2010).

13. W. E. Yudiatmaja, Y. Yudithia, T. Samnuzulsari, S. Suyito, and E. Edison, in IOP Conf. Ser. Mater. Sci. Eng. (Institute of Physics Publishing, 2020).

14. W. E. Yudiatmaja, D. Kristanti, I. Y. Prastya, Y. Yudithia, T. Samnuzulsari, S. Suyito, and D. P. Safitri, E3S Web Conf. 232, 1 (2021).

15. W. E. Yudiatmaja, E. Edison, T. Samnuzulsari, Y. Yudithia, S. R. I. Rezeki, S. Suyito, D. Akbar, and A. Alfiandri, IOP Conf. Ser. Earth Environ. Sci. 755, 012076 (2021).

16. D. Akbar, I. Irman, W. E. Yudiatmaja, and K. Fadli, IOP Conf. Ser. Earth Environ. Sci. 724, 012103 (2021).

17. T. Samnuzulsari, D. Kristanti, H. Susanto, W. E. Yudiatmaja, M. K. Yunanto, S. D. Meilinda, and D. Akbar, IOP Conf. Ser. Earth Environ. Sci. 824, 012104 (2021).

18. F. Nofiyanti, D. Z. Nasution, D. Octarina, and R. M. W. A. Pradhipta, E3S Web Conf. 232, 02031 (2021).

19. R. M. W. A. Pradhipta, P. Pusparini, and Fi. Nofiyanti, E3S Web Conf. 232, 04010 (2021).

20. D. Akbar, A. Setiawan, R. Prayuda, A. Putra, A. Aznor, and W. E. Yudiatmaja, J. Phys. Conf. Ser. 1655, 012144 (2020). 